malacologist some sixty-five years ago from Mauritius, whither it had been brought in some unknown manner from tropical Africa, its original home. Col. Godwin Austen ${ }^{1}$ has told the story of its introduction into Calcutta, while Mr. E. E. Green ${ }^{2}$ has published a report on its prodigious increase in Ceylon, when once its eggs had been carried (accidentally on a cabbageleaf) into a suitable locality. Fortunately, it is largely a feeder on decaying vegetable and animal matter, and therefore does little harm to crops or gardens, and has even its value as a scavenger. Since, however, I found the maggots in the dead snails, I have noticed that the appearance of blue-bottles in this part of Calcutta invariably coincides with a heavy mortality in the moilusc, which appears to be subject occasionally to some kind of fatal epidemic and also perishes in large numbers after egg-laying at the beginning of the rainy season and during dry spells in and at the end of that season. In one instance investigated the mortality was due not to disease or weakness or to meteorological conditions, but merely to the fact that the snail was enormously abundant and that large numbers of individuals were crushed by people walking on garden paths in the evening.

I have thought these facts worth putting on record as illustrating the delicate balance of Nature and the danger of introducing apparently harmless or even stemingly beneficial animals into a new country. N. Annandale.

Indian Museum, Calcutta, November 19.

\section{Remains of a Fossil Lion in Inswich.}

In rglo I discovered a rich bone-bed in a section of Stoke Hill at Ipswich, the deposit in which it occurred being $30 \mathrm{ft}$. below the surface. The results of the researches then undertaken were published in vol. xiv., part I, of the Proceedings of the Suffolk Institute of Archæology and Natural History.

As a portion. of Stoke Hill is now being cut away for railway sidings, a continuation of the same section is exposed, and with the permission and kind assistance of Mr. A. Woolford, G.E. Railway District Mechanical Engineer, I have been able to work for the past month upon it.

To the animal remains found in I9Io, which included large cave-bear, mammoth, large horse, Bos primigenius, smaller ox, deer, and bird, I have now added teeth of the largest cave-lion yet discovered, with the exception of the Crayford specimen in the Spurrell collection. These were identified for me by Dr. Smith Woodward and Dr. Andrews, who also examined and named a large assortment of teeth and bones from the site. The list of remains is daily being added to, and a massive skull of deer, with other bones, a tooth, and an antler with a base measuring ro in. in circumference, still await identification. The position of the tines suggests reindeer. With the help of a grant from the Percy Sladen Research Fund, I am able to continue the work with the care that it requires, and am employing special workmen for the purpose.

The question of the relation of Glacial deposits to these ancient land-surfaces is, of course, of paramount importance, especially as a small number of worked flints have been found closely associated with the animal remains. For this purpose pits are being dug to a considerable depth below our present groundlevel in order to ascertain the constituents of the strata below.

Rookwood, Ipswich, December I\%.

1 Proc. Mal. Soc., yol. viii., p. 147 (roo8).
2 "Report on the Outbreak of Achatina futica" in Circulars and Agricultural Journal of the Royal Botanical Gardens, Ceylon (rgro).

No. 26 I 7 , vOL. IO4]

\section{Promotion of a Plumage Bill.}

MAY I announce through the columns of Nature the formation of a "Plumage Bill Group," designed to fight the plumage trade by means of publicity to the facts and of pressure upon the Government to bring in a Bill forbidding the importation of all birds' skins for millinery purposes, except poultry, ostrich, and eider-duck? Sir Charles Hobhouse is the president of this group; Lt.-Col. Swinburne, of 23 Eaton Place, S.W.r, its treasurer; and Mr. W. Dewar, of 8 Kenilworth Court, Putney, S.W.I5, its hon. secretary. The group is in need both of funds and of assistance, and the former will be very gratefully received by the treasurer, and the latter as gratefully considered by the zecretary and the committee.

We feel that a vigorous effort must be made to end the yearly massacre of the world's most beautiful and interesting species of wild bird-a massacre so merciless and extensive as seriously to threaten the extermination of a large number of species, and thus to throw out of gear the great work of evolution. Nor is there any honest or valid argument for the traffic, since this immense drain upon natural resources is for no other purpose than to feed the profits of a small band of East End traders and to satisfy the frivolity of some women.

December 17 .

\section{The Deflection of Light during a Solar Eclipse.}

THERE can scarcely be a downward rush of cold air in places deprived of the sun's radiation during an eclipse as suggested by Prof. Anderson. This would happen only if the upper layers of the atmosphere were cooled more than the lower, and if the cooling were sufficient to bring the temperature-gradient near to the adiabatic. As it is, however, the effect of an eclipse should be to cool the lower layers more than the upper, and so to decrease the temperature-gradient. Moreover, if cooling caused convection movements, we should have upward currents as well as downward, and a development of cumulus clouds would result from the passage of the moon's shadow.

C. J. P. CAVE.

Ditcham Park, Petersfield, December 19.

\section{INDUSTRIAL RESOURCES OF INDIA. ${ }^{1}$}

A $\mathrm{S}$ explained in a preface by $\mathrm{Sir}$ Thomas $\mathrm{H}$. Holland, the president of the Indian Muni-
tions Board, this handbook was originally prepared in connection with the exhibit of the Board at the exhibitions held in Bombay and Madras in the winter of $1917-18$. It was intended to show what had been done to develop India's industrial resources for war purposes. It has now been enlarged so as, in some measure, to indicate the general industrial development which has taken place during, and on account of, the war, and it discusses the possibility of future progress.

The Board was created in 1917 with the view of relieving the United Kingdom, so far as possible, from the necessity of meeting India's demands for war purposes, and particularly for the supply of the forces in India, Mesopotamia, and Egypt. Its functions consisted not only in utilising Indian resources to the utmost extent, but also in controlling and regulating imported

1 Indian Munitions Board. Industrial Handbook, 19rg. Revisec Edition. (Calcutta: Superintendent, Government Printing, 19rg.) Price 2s. $3 d$. 